\title{
Qualitative Research: A Case for a Multi-Angle View to Enhance 'Validity'
}

\author{
Ashfaq Ahmad Khan ${ }^{1}$ \\ ${ }^{1}$ Lecturer in Accounting, UNE Business School, University of New England, Armidale, Australia \\ Correspondence: Ashfaq Ahmad Khan, Accounting, UNE Business School, University of New England, \\ Armidale, NSW 2351, Australia. Tel: 612-6773-2711. E-mail: akhan27@une.edu.au
}

Received: July 2, 2014

Accepted: August 17, 2014

Online Published: August 22, 2014

doi:10.5539/ijbm.v9n9p29

URL: http://dx.doi.org/10.5539/ijbm.v9n9p29

\begin{abstract}
Qualitative and quantitative organizational research methods have been fiercely debated with regards to their 'value' in terms of the 'validity' and 'generalizability' of their respective research outcomes. Qualitative or phenomenological research paradigm requires a 'holistic' approach to analysing a particular phenomenon in order to address 'validity' and 'generalizability' issues, and therefore necessitates more 'intense' and 'comprehensive' approach to data analyses. This conceptual paper adds to the current debate among the positivists and the phenomenologists on the superiority of a particular research method and, resorting to the dialectical analysis, contributes to the current literature on organizational research methods through conditionalising the 'validity' and 'generalizability' of the research outcomes under the qualitative research paradigm to the use of appropriate 'research design'. Using the microfinance sector's paradigm shift of the 1990s as a case, the paper argues that, under the qualitative research paradigm, 'viewing' and 'analysing' a qualitative set of data with a combination of two or three established theoretical constructs would help the researcher overcome the relative 'flaw' or 'incapacity' of a single theoretical construct to address all aspects of a social phenomenon under investigation, and therefore, not only enhance readers' understanding of the issue but also conclude the research with relatively more 'valid' and 'generalizable' outcomes.
\end{abstract}

Keywords: qualitative research paradigm, validity and generalizability issues, dialectic analysis, organizational research methods

\section{Background}

Theoretical and philosophical issues are considered to be of utmost significance in carrying out high quality research. The literature suggests that the relationship between theory (Note) and data (Note 2) needs to be close and its understanding and appreciation by researchers is of vital significance for the success of their research endeavour. For improving the quality of a project, the researcher should consider the importance of connecting theory and data, although not doing so would not result in a total quality loss (Easterby-Smith, Thorpe \& Lowe, 1991, p. 21). Two research paradigms have been used in the literature and appear more frequently - quantitative and qualitative. Qualitative research paradigm is usually criticized from the point of view of the 'validity' and 'generalizability' of the final outcomes.

There has always been a debate among various schools of thought with a peculiar predisposition to one of the two research paradigms arguing on the suitability and intrinsic value in terms of 'validity' and 'generalizability' of research outcomes under a particular paradigm. The quantitative paradigm, also known as the positivistic approach, has been mainly associated with research in the field of the natural sciences, such as physics, biology, botany, and chemistry. Under this paradigm researchers see knowledge objectively and reality as something tangible and not vague (Hussey \& Hussey, 1997; Remenyi, Williams, Money, \& Swartz, 1998). Hussey and Hussey (1997, p. 52) argue that, according to positivists, "laws provide the basis of explanation, permit the anticipation of phenomena, predict their occurrence and therefore allow them to be controlled". Positivists maintain that research in the context of social sciences can also be carried out in the same way as in physical sciences (Rice \& Ezzy, 1999). Many established researchers, for instance, Piore, 1983; Strauss \& Corbin, 1990, Layder, 1993, and Van Maanen, 1983, on the other hand, support the use of the qualitative research paradigm. They posit that the paradigm potentially can advance knowledge if properly resorted to in conducting research. Layder (1993), for instance, elaborate extensively in his book on the power and capacity of the paradigm to help build a new theory and/or modify an 
existing one. Under the paradigm researchers must base interpretation of their research findings on empirical data, their own experience and perceptions, and the existing state of knowledge on the research issue. Following these qualitative paradigm guidelines could potentially give rise to a new theory in the area of research, which, in turn, could extend the boundaries of human understanding on the issues.

This paper contributes to the literature in two ways: firstly, it highlights the significance and the value-laden influences of individuals and groups involved in the process of the construction of social practices and their mutual dialectics they employ along the way to reach the practices' institutionalisation; secondly, it contributes to the literature on the organizational research methods, suggesting a 'holistic' approach to investigating a research issue under the qualitative research paradigm by 'viewing' and 'analysing' the research issue and relevant empirical data from the lenses of a combination of some established theoretical perspectives, rather than just one, and 'explaining' how the distinct parts of a set of empirical data addresses the peculiar aspect(s) of the research issue at hand. The author argues that the 'flaw' or 'incapacity' in a particular theoretical lens to holistically 'view' all 'allied' aspects of a social phenomenon will be overcome by the second (or third) theoretical lens, and hence enhance the intelligibility of the research findings in addition to contributing to their 'validity' and 'generalizability'.

The remainder of the paper is structured as follows: section 2 elaborates on the 'case' the author has used to demonstrate how an effective 'research design' that employs a combination of two established theoretical conceptualization to 'view' and 'analyse' the empirical data of a qualitative research project enhances the 'validity' and 'generalizability' of the project's findings, in addition to facilitating readers' understanding of the phenomenon under investigation. Section 3 compares and contrasts the two dominant research paradigms in the light of the literature and the objectives of this study. Section 4 sheds light on how effectively a carefully selected set of two established theoretical frameworks addressed all pertinent aspects of 'the case' the author has used in the paper to shed light on the significance of a good research design for a qualitative research study. Section 5 concludes the paper with directions for future research in the area.

\section{The Microfinance Sector's Paradigm Shift-'The Case'}

The microfinance sector's paradigm shift of the 1990s provides a befitting example of how an appropriate combination of two established framework help us understand the sector's adaptation to externally dictated change conditions and how each distinct part of the change is best analysed using a separate theoretical framework. Microfinance is a powerful development tool with which to alleviate the problem of poverty through providing a range of financial services to the poor, such as savings products, remittances, and micro-insurance products (Haq, Skully \& Pathan, 2010). The real essence of all microfinance efforts around the world is to enable the poor to break the cycle of poverty by establishing and nourishing small businesses. The international donor community (Note 3) and governments have had substantial financial and non-financial investments in developing and providing subsidized financial services through formal microfinance institutions for the poor on the premise that they have limited access to the formal mainstream financial institutions (see Mohan \& Potnis, 2010; Rahman \& Luo, 2011).

In the early stages most microfinance programs have had little direct competition and their main challenge was to reach the poorest of the poor and provide efficient services to their clients. The stress on self-sustainability on the part of donors, which can be traced back to the period from the early to mid-1990s (Fernando, 2006; Robinson, 2001 and 2002; Baydas, Graham \& Valenzuela, 1997; CGAP, 1996; Gonzalez-vega \& Schreiner, 1997; Dichter, 1996; Rogaly, 1996), posed a new challenge to the microfinance institutions around the world. Instead of looking for subsidized financial resources from international donor agencies, microfinance institutions now have to rely on good and commercial banking practices to achieve self-sustainability and thereby ensure their long-term survival. Donor agencies emphasize reducing operational costs, charging a market rate of interest (or even more), and improving profitability. The microfinance institutions' objective is, thus, not only to reach large numbers of the poor, but also to ensure their own survival and sustainability through adopting prudent commercial practices (Gurgand, Pedersen \& Yaron, 1996). Sustainable organizations ensure a positive rate of return on all the stakeholders' investments (Edgcomb \& Cawley, 1994, p. 77). Edgcomb and Cawley (1994, p. 86) further argue that sustainable institutions do not need subsidized financial resources from outside sources, and are able to generate enough profits from their operations to fully meet their present and future financing requirements. These organizations are not dependent on the donor community for subsidies. These new issues came as 'external disturbances' for the MFIs, which were previously heavily dependent on the donors' subsidized funding, and they had to adapt and reorient to the changed external conditions.

The Aga Khan Rural Support Programme (AKRSP)-one of the prominent microfinance institutions in Pakistan, is one of the examples of the paradigm shift where its microfinance division, responding to the donor community's dictated paradigm shift, underwent drastic internal adaptation and reorientation, and eventually transformed into 
an entirely commercial setup - the First Microfinance Bank Limited. Just like the microfinance sector, its individual constituents such as the AKRSP also adapted and reoriented to better suit the demands of their external environment. The change AKRSP underwent has two distinct aspects; first, the internal adaptation and reorientation of the microfinance division of the AKRSP to the changed external circumstances and, second, its passive submission to the changed environmental conditions. Therefore, the study was best explored and analysed using a combination of theoretical frameworks-Laughlin's (1991) Model of Organizational Change and institutional theory (DiMaggio \& Powel, 1983) to placate the two aspects of the research issue (see Khan, 2008). The study provided insights into the successful adaptation of the AKRSP as it had to tailor all of its tangible and intangible organizational elements in response to the changed external conditions to ensure its survival and sustainability, eventually transforming from a donor based institution to a self-sustainable, commercial institution. The adaptation and eventual transformation of the Banco Sol in Bolivia of Latin America and the Caribbean region into a commercial setup is another example of the sector's paradigmatic change. India's SKS Microfinance and Peru's MiBanco are among the microfinance institutions that substantially adapted to the 'commercial microfinance' paradigm in an attempt to ensure their survival in the long run.

\section{Comparing and Contrasting Research Paradigms}

\subsection{The 'Qualitative' or 'Phenomenological' Research Design}

Patton (2002, p. 145) refers to qualitative research as the "first and foremost" method of conducting research. The use of the method has spread, beyond the discipline of psychology, across several disciplines in the social sciences, whereas the use and spread of quantitative method in the discipline mostly remained constrained by the expansion of the discipline itself (Cassell \& Symon, 2011). The inception of the Phenomenological research paradigm, mostly named the 'qualitative research paradigm' in the literature, can be traced back to the research works in the fields of social science disciplines, including sociology, anthropology, nursing, education and health-related studies, business and economics, and psychology (Black, 2002; Fossey, Harvey, McDermott \& Davidson, 2002). In short, "social science research involves investigating all aspects of human activity and interactivity" (Black, 2002 , p. 1), and qualitative research design better addresses such issues in most situations. This type of research is largely influenced by the researchers' own social surroundings and perceptions about a particular research issue (Hussey \& Hussey, 1997; Patton, 2002). See Munhall (2011) for extensive discussions on the peculiar aspects of the research design. The paradigm rose to prominence because of the stiff criticism of and the limitations of the positivistic approach to research issues pertaining to the field of social sciences. The paradigm is also known as phenomenological (Not 4) because of its apparent approach to conducting research. The researcher using this philosophical package is allowed to use his sensations, intuition, and reflection in interpreting the research findings (Hussey \& Hussey, 1997).

Easterby-Smith et al., (1991, p. 23), while pointing to the distinguishing marks of the paradigm, argues that this paradigm considers knowledge, reality or truth as something constructed or brought into existence through the social interaction among people. In other words knowledge or reality, or truth is not something independent of mutual human interactions, rather it is there only because it is accepted and given meaning by human beings. It does not consider knowledge or truth about a real life phenomenon as something that exists in advance and needs to be discovered, while the positivist philosophical framework does. 'Qualitative research' is not limited to a narrow range of research areas. It resorts to several methods to conduct research on issues pertaining to wide variety of topics in social settings. Moreover, the findings under this paradigm need not necessarily be expressed in quantitative terms (Strauss \& Corbin, 1990; Fossey et al., 2002). The method boasts flexibility that is essential for inductive approach to knowledge finding (Munhall, 2011). Many researchers (for instance, Piore, 1983; Strauss \& Corbin, 1990, Layder, 1993; Van Maanen, 1983) support the use of the qualitative research paradigm. They posit that the paradigm potentially can advance knowledge if properly resorted to in conducting research. Layder (1993), for instance, elaborate extensively in his book on the power and capacity of the paradigm to help build a new theory and/or modify an existing one. Under the paradigm researchers must base interpretation of their research findings on empirical data, their own experience and perceptions, and the existing state of knowledge on the research issue. Following these qualitative paradigm guidelines could potentially give rise to a new theory in the area of research, which, in turn, could extend the boundaries of human understanding on the issues.

\subsection{The 'Quantitative' or 'Phenomenological' Research Design}

The positivistic approach considers every social situation as completely independent of other situations and as a 'reality' which needs to be found out about or researched in conjunction with the nature of its surroundings and the perceptions of the individuals involved (Easterby-Smith et al., 1991; Remenyi et al., 1998). The literature argues that a 'blanket application' of the criteria of reliability, validity, generalizability, and replicability that are derived 
from the positivist research paradigm, to the qualitative research is not appropriate; a stance that has resulted in the introduction of alternative criteria, which would not be as rigorous as under the positivist design but still ensure internal and external validity (see, Cassell \& Symon, 2011).Strauss and Corbin (1990) argue that, unlike the positivist paradigm, the qualitative research paradigm is not rigid and is adaptable to conducting research on a variety of social issues. It helps researchers to understand and describe a social phenomenon in its naturally occurring state, without having to control different variables (Van Maanen, 1983). Where quantitative or positivists' research methods fail to come up with a way resolve an issue pertinent to a social setting, qualitative methods, due to their flexible approach to conducting research, can help researchers reach an amicable solution (Strauss \& Corbin, 1990). Remenyi et al. (1998) point to the advantage of using the qualitative research paradigm and argue that, unlike the quantitative philosophical research base, its approach to research is holistic. It does not try to make the research endeavour unrealistic by simplifying the research issue through limiting the number of variables to a manageable level and controlling the research settings. Researchers resorting to the qualitative philosophical framework in conducting research can more convincingly claim their research to be more realistic, given the fact that they carry out their research on a social issue in their real life setting without manipulating or controlling any variables (Yin, 2003, p. 13).

This study uses the microfinance sector's paradigm shift of the 1990s, where the sector's operational emphasis underwent a drastic shift in approach from a 'social service' stance to commercialism in operation, as a base to argue for a tailored approach to handling research under the qualitative research paradigm. Given the paradigm's overall flexible approach, this paper argues that in order the overcome the opposing critics' (the positivist school of thought) reservations regarding the internal and external validity and generalizability of such a study's outcomes, qualitative researchers are best placed using and deriving 'support' from a combination of theoretical frameworks rather than just one. An alternative could be the triangulation of available data and analysis resources - data, investigator, theory, methodological, and environmental (Guion, Diehl \& McDonald, 2011).

\subsection{The Dominance of a Social Practice}

Social practices get constructed over time due to the actions and 'non-actions' of individuals and groups, and have characteristics peculiar to their social, economic and religious backgrounds. Kilfoyle and Richardson (2011) associate the individuals' and groups' actions into those they do out of their free will and those that are directly or indirectly influenced by their respective position and norms in the society. Different individuals and groups, through a process of what we call the 'tug of war', exert influence on a social practice and tailor it to suit their peculiar requirements and desires before it is accepted as a 'valid' and 'institutionalised' (see also, Hotho, Saka-Helmhout, \& Becker-Ritterspach, 2014). The dialectics of these individuals and groups and the eventual reconciliation between them sets a social practice at a position which encompass the relative powers and the magnitude of influence of each of the individuals and groups involved in the process.

Phenomenologists and positivists, through a similar process, have established the relative significance of each of the two prominent organizational research methods. As the nature of the dialectics and the process of reconciliation dictates, the method that boasts support of more 'influential' scholars is 'perceived' to be of relatively higher value in terms of the 'validity' and 'generalizability' of their respective research endeavours.

\section{The Qualitative Research Design's Strength in Analysing 'the Case'}

The literature suggests that the case of organizations undergoing radical changes in which they reorient and transform in response to external environmental 'disturbances' can be best elaborated on by employing a combination of two theoretical lenses. Different studies have resorted to a combination of two or three theoretical frameworks (see Erakovic \& Wilson, 2005; Eisenhardt, 1988; Tolbert, 1985; Shanikat, 2008). Thus, in a situation, where one theoretical framework fails to address all aspects of the research problem at hand, researchers tend to apply a combination of two or three theoretical frameworks. A similar sort of situation did the microfinance sector encounter when it, 'forced' by the sector's donor community, gradually shifted its operational focus from its 'social service' stance to a 'commercial' approach in an attempt to ensure its long-term sustainability. A microfinance institution, in its policies and practices, is not expected to be rigid and unsusceptible to external environmental pressures. It ought to tailor its policies and practices and adapt to the demands of the external environment. The external environment, if it gets turbulent, exerts pressure on a microfinance institution to adjust its policies, practices, rules, norms, objectives, goals, and overall structure and make them harmonised with changed external conditions.

The literature suggests that organizations try to resist a change and stay unchanged in their current balanced state (Laughlin, 1991). Moreover, they will show inertia and try to click back to their original state, if possible (Miller \& Friesen, 1984). They will only change when 'forced', 'kicked', or 'disturbed' by a turbulent external environment 
strong enough to overcome the organization's resistance (Laughlin, 1991). The study focused on the actual visible changes in the Aga Khan Rural Support Programme's 'tangible' and 'intangible' organizational elements - the 'interpretative schemes' (mission, purpose, beliefs, norms, values, culture, rules, philosophy), 'design archetypes' (overall organization structure, decision processes, communication systems), and the 'sub-systems' (tangible organizational elements such as staff, departments/divisions, business premises) - in response to the external 'disturbances' or changed external circumstances. In the microfinance sector case described above, the donor community's changed thinking and approach as to the long-term sustainability of the microfinance institutions (MFIs) from providing subsidized financial resources to a strong emphasis on self-sustainability on the part of the MFIs, the resulting competition among the MFIs, and increased government regulations, all constitute external environmental 'disturbances'. External environmental disturbances/kicks/jolts (Laughlin, 1991), following a particular pathway or track (Laughlin, 1991), penetrated through the organization causing it to initiate internal adaptation and reorientation to the changed external circumstances. The literature suggests that these 'jolts', 'noises', 'kicks', or 'external disturbances' trigger a change within different elements of an organization and cause it to adapt, reorient, and/or transform accordingly (Laughlin, 1991; Pettigrew, 1987; Greenwood \&Hinings, 1988).

\subsection{The Institutional Theory Lens-Why Did the AKRSP Not Resist the Change?}

The origin of institutional theory can be traced back to around the 1950s. It has been widely used in research studies in the field of economics, political science, and sociology (Scott, 1995). Describing the theoretical underpinnings of institutional theory, Weick (1996, p. 567) claimed that social contexts in which microfinance institutions operate have considerable control over them and are capable of tailoring their tangible and intangible organizational elements to a large extent. Selznick $(1957$, p. 16) defined "institutionalization" as: something that happens to an organization over time, reflecting the organization's own distinctive history, the people who have been in it, the groups it embodies and the vested interests they have created, and the way it has adapted to its environment. Scott (1995, p. 13) described the structures of organizations as "shared knowledge and belief systems". The essence of institutional theory is that an organization of a particular type experiences a kind of pressure that compels it to adopt certain policies and procedures if it is to be seen as a good member of that particular industry (Barley \& Tolbert, 1997). If an organization is willing to be known as part of or a legitimate member of a particular group of organizations in the same industry, it has to inculcate the norms and values associated with that particular industry by the general public, referred to as "rules of knowing" (Mills \& Murgatroyd, 1991, p. 1) into its organizational structure. The new 'neoinstitutionalism', however, has necessitated a re-visit of the theory of isomorphism and argues it does not completely apply to all situations (see, Lounsbury, 2008).

Several studies in the management field have linked the survival and sustainability of a business enterprise to its proper amalgamation with the institutional environment it is operating in. To ensure a firm's long term survival and sustainability it should be linked to or merged in prevalent local institutions within the same industry. It must conform to industry norms and values, and the expectations of the society at large (DiMaggio \& Powell, 1983; Meyer \& Rowan, 1977; Baum \& Oliver 1991; Oliver, 1997). Snow (1999) also, while discussing the sustainability issues of a microfinance institution, hints towards its prudent adoption of industry norms and values. To make microfinance institutions self-sustainable in the long run, they have to be harmonized with other institutions in the same industry with respect to their policies and practices and other organizational elements. In other words, they should not look like standing alone but should appear to be part of the mainstream local institutions (Snow, 1999). Cernea (1993), while analysing the causes of failure of most of the World Bank's poverty reduction projects in Asia, Africa, and Latin America, blamed the lack of incorporation of social factors such as local norms, values, practices, culture, and people's interaction and dealings with each other-all regulating forces behind their specific behavioural patterns, in the implementation of these programs for their failure.

Institutional theorists posit that willingness to submit to the institutional influences on the part of organizations is the essence of institutional isomorphism. These institutional influences, which shape organizational behaviours, lead to achieving sustainability, legitimacy, and social support. These influences include, but are not limited to, a country's regulatory structures, and rules and laws of concerned government agencies (Oliver, 1997). Although theory indicates that smaller organizations mimic larger organizations in their field, actual outcome of change for an organization may vary among industries (see, for instance, Lowrey \& Woo, 2010). In order to achieve long term sustainability, an organization must also earn a general perception of a 'legitimate' existence from the society in addition to showing a sound financial footing in terms of monetary achievements. Social players in an industry confer the status of 'Legitimacy' on organizations (Bartram, 2011). In the literature, we encounter two types of 'organizational legitimacy': first, one granted by regulatory agencies and second, that is bestowed upon the organization by the general public in form of endorsement of its rules, norms, values, and overall organizational 
behaviours (Deephouse, 1996). Deephouse (1996) found that organizations benefit from organizational isomorphism in the form of increased legitimacy in the sight of the general public. Also, the 'coercive' pillar of institutional theory suggests that organizations which are directly or indirectly dependent on other independent entities for financial and/or non-financial resources, must respond positively to the changes in policies of these independent entities in order to survive in the long run.

The internal adaptation and reorientation of the Aga Khan Rural Support Programme (AKRSP) in response to external environmental disturbances to ensure its long term survival and sustainability (Note 5) is a good example of how the microfinance institutions (MFIs) underwent a change under the sector's paradigm shift. The MFI had to prove its beneficial and legitimate existence to the donor community on which it was dependent for resources financial and non-financial support, and to the society at large, to ensure its survival. The AKRSP passively submitted to the new external environmental conditions because to remain in the industry it had to accept the "rules of knowing" (Mills \& urgatroyd, 1991, p. 1) that had started to prevail in the industry. It had to tailor its policies and rules, objectives, and overall organizational structure to prove itself as a legitimate member of the industry. In other words, it had to show itself as a proper carer of industry norms and values. Thus, institutional theory best explained this part of AKRSP's adaptation and reorientation to changed external conditions. The actual changes, tangible as well as non-tangible, into the MFI's overall organizational structure could be best explained from the theoretical perspective of Laughlin's model of organizational change (1991).

\subsection{Organizational Transformation}

A number of frameworks have been devised by organizational and other researchers for the analysis of organizational change (Tyrrall \& Parker, 2005). The 'organizational change' dimension of the microfinance sector's paradigm shift could be best analysed by the Laughlin's (1991) organizational change theoretical conceptualization (see figure 1 below).

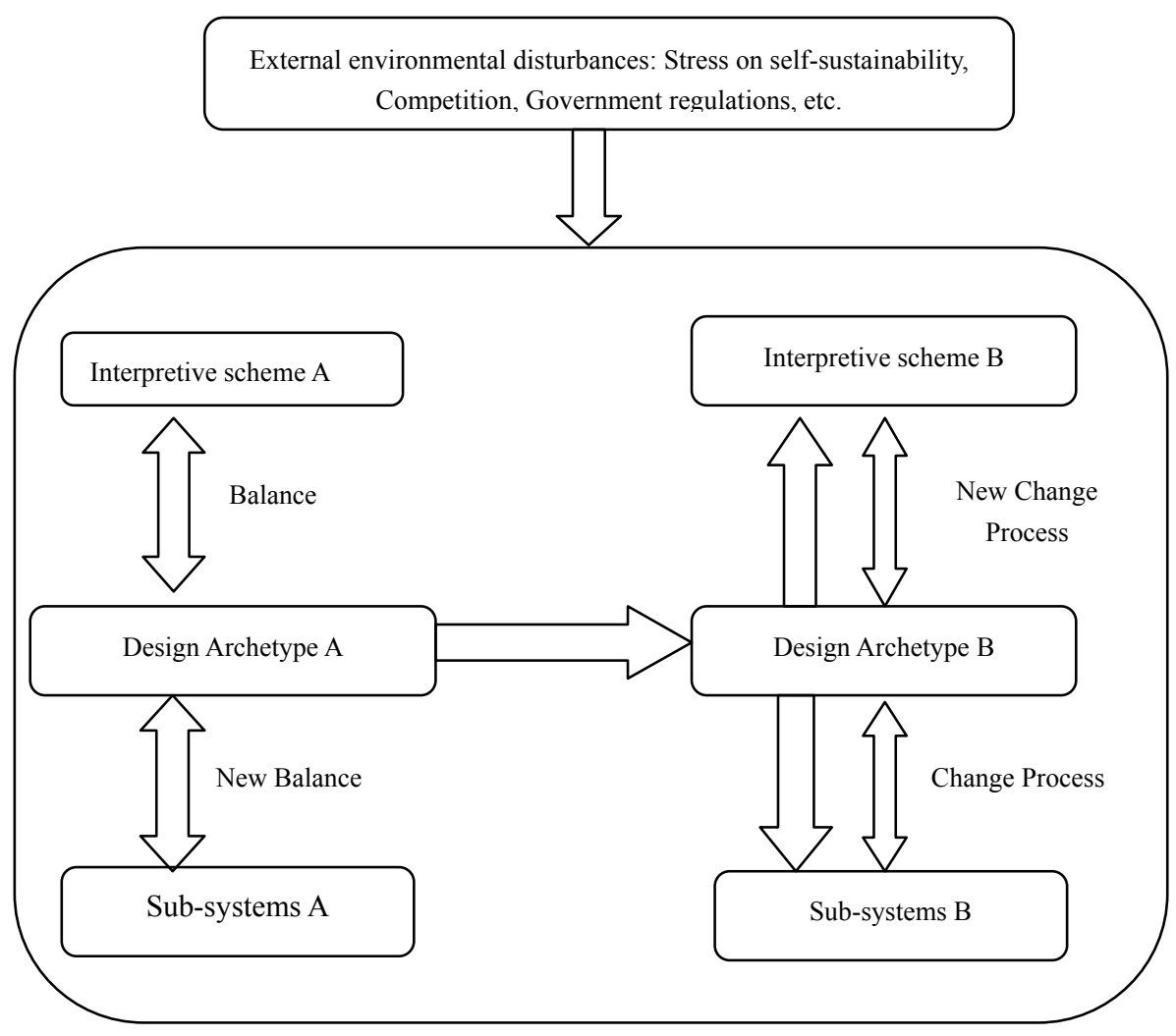

Figure 1. Laughlin's model (1991) for interpreting organizational change

Source: Adapted from Laughlin (1991).

It is an established premise in the literature of organizational studies that organizational change can be traced to the track or pathway an external disturbance takes through the organization (see, Laughlin, 1991). External 
environmental disturbances/kicks/jolts, following a particular 'pathway' (Laughlin, 1991, p. 209) or 'track' (Greenwood \& Hinings, 1988, p. 294), penetrate into the organization, stirring its existing setup and compelling it to tailor its organizational elements in response. Organizations, thus, instigate an internal adaptation and reorientation process of varying magnitude and pace along different 'tracks' or 'pathways' in order to tackle the changed external conditions (Laughlin, 1991; Greenwood \& Hinings, 1988). Figure 2 below explains these terminologies.

\begin{tabular}{c|l|}
\cline { 2 - 2 } Interpretative Schemes & $\begin{array}{l}\text { Level 1: Values/norms/beliefs/culture } \\
\text { Level 2: Objectives/mission } \\
\text { Level 3: Set rules/policies }\end{array}$ \\
\cline { 2 - 2 } Design Archetype & $\begin{array}{l}\text { Organizational structure, Communication systems, Decision } \\
\text { processes. }\end{array}$ \\
\hline Sub-systems & $\begin{array}{l}\text { Tangible organizational elements: For instance, premises, staff, } \\
\text { machinery, location, finances, etc. }\end{array}$ \\
\hline
\end{tabular}

Figure 2. 'Design archetype', 'interpretative schemes', and 'sub-systems' and the nature of the elements in laughlin (1991) model

Source: Adapted from Laughlin (1991).

The literature suggests that all the three organizational elements remain in close connection to each other, each one supporting the other. A major change in one element necessitates a change of the same pace in the others (Greenwood \& Hinings, 1988). In other words, they should "...bind the organization together and make it a coherent whole" (Laughlin, 1991, p. 213). According to Tyrrall and Parker (2005), however, the organizational change model given by Laughlin (1991) emphasizes more on the design archetypes of an organization. Since the adjusting and tailoring of design archetypes of an organization is a job that pertains purely to the senior management, Tyrrall and Parker (2005) argue that in most studies that resort to Laughlin's model the focus is on looking at the organizational change from the top management point of view rather than other staff levels.

\subsection{Organizational Response}

A microfinance institution operates on the basis of certain policies and procedures for achieving its core objective of alleviating poverty and embracing prosperity and sustainability on a long term basis. After being hit by external environmental jolts, a change process is initiated within the organization. The resultant changes in the organizational setup in response to these disturbances are of a different velocity and magnitude.

Table 1. Laughlin's typology of organizational change in response to external environmental 'disturbances'

\begin{tabular}{ll}
\hline i. No Change & Inertia \\
\hline ii. First order change (Morphostatic) & 'Rebuttal' / 'Reorientation' \\
\hline iii. Second order change (Morphogenetic) & 'Colonization' / 'Evolution'/ Transformation \\
\hline
\end{tabular}

Source: Adapted from Gray, Walters, Bebbington \& Thompson (1995).

Table 1 above shows various degrees of changes an organization may adopt depending on how strong the external pressure for change is and how strong are the organization's elements coupled together. The change may be shallow and less intense, or it may go very deep into the organizational setting. Laughlin (1991) calls them morphostatic (first-order change) or morphogenetic (second-order change) changes respectively.

After a reasonable period of time in operation, after internal change process is complete, the MFI achieved 'balance' (Laughlin, 1991) and settled at a particular position with respect to its polices, practices and overall organizational structure that is dominated by commercialism principles in all its operations - the First 
Microfinance Bank Limited. See, Campanale, Cinquini, and Tenucci (2010) for details on the dynamics of organizational response to changed external conditions.

\section{Conclusions}

Kassim, Tahajuddin, Hassan, Shamsuddin and Sulaiman (2011) view organizational change as one the two approaches: Mainstream (positivist), where a set of independent variables bring about a change in 'organizational change' dependent variable; and, alternative (interpretive), where organizational change instigates as a result of the interaction between social actors and the wider environment. The AKRSP's change process resonate more with the later view, and can be best analysed under the qualitative research design. Any organization, depending on its strength, size, and the nature of its relationship with other organizations, has to adapt, reorient, and transform, when 'kicked', 'jolted', or 'disturbed' by turbulent environmental conditions, especially if the environmental turbulence is initiated/caused by an organization on which it is dependent for resources: capital, customers, expertise, technology, etc. Researchers argue that the process of organizational adaptation and transformation in response to external environmental pressures completes only with the organization settling down and achieving a new 'balanced' state with respect to all its organizational elements, tangible as well as intangible. The next step would be for the organization to achieve harmony among these elements. Successful organizational transformation entails successful adoption of these changes (Isabella, 1990; Greenwood \& Hinings, 1988; Gioia \& Chittipeddi, 1991), and can be best explained using a distinct theoretical framework.

As with continuous developments in the theoretical stance of institutional theory, Laughlin's organizational change model is also not without flaws (see, Fraser, 2012). Had the researcher resorted to only the Laughlin's Model of Organizational Change, the 'organizational change' part of the social phenomenon he investigated would have been 'explored' in complete detail, but the MFI's passive submission to an externally dictated change and the subtle reasons thereof would have remained unexplored leaving readers with a huge 'gap' wanting a desperate 'fill-up', and vice versa. Various studies have resorted to a combination of two theoretical frameworks. For instance, in analysing the key contributors to organizational transformation in five New Zealand public-sector enterprises, Erakovic and Wilson (2005) employed a combination of 'institutional theory' (DiMaggio \& Powell, 1983 ) and 'resource dependency' theory (Pfeffer \& Salancik, 1978). In exploring the competition issues in retail sales, Eisenhardt (1988) employed a combination of agency theory and institutional theory. Tolbert (1985) combined Institutional Theory and Resource Dependency theory to look at the data while studying organizational change in institutions of higher education. Shanikat (2008), while analysing the organizational change aspect in a telecommunication industry player, resorted to three theoretical underpinnings - institutional theory, resource dependency theory and Laughlin's organizational change model, to address the three distinct aspects of the social phenomenon he investigated. Thus, in a situation, where one theoretical framework fails to answer all aspects of the problem, researchers ought to apply a combination of two or more theoretical frameworks to comprehensively address all 'allied' aspects of a social phenomenon under investigation.

A combination of two or three theoretical frameworks to study and analyse organizational change is resorted to in order to explain and understand the two differing phenomena associated with the internal adaptation of the Microfinance Division of the Aga Khan Rural Support Programme in response to changed environmental conditions, and to overcome the shortcomings of each of the two models in individually analysing all aspects of the change. The deployment of a combination of two established theoretical conceptualizations to the microfinance sector's paradigm shift indicated that complex social phenomena that comprise of several intangible aspects lend themselves to a thorough investigation only if suitable theoretical frameworks 'view' and 'analyse' those intangible 'allied' aspects of them one by one. Institutional theory (DiMaggio \& Powel, 1983) best explained the AKRSP's passive submission to these environmental disturbances and Laughlin's (1991) Organizational Change Model its internal adaptation, reorientation, and subsequent transformation to an independent commercial bank. With the recent shift, however, of the organizational change literature to neoinstitutionalism that has necessitated a re-visit of the theory of isomorphism (Lounsbury, 2008), organizational change processes can be viewed from an entirely different angle, and thus further research is needed in this area. I assert that in order to enhance the 'validity' and the 'generalizability' of a research endeavour under the qualitative or phenomenological research paradigm, researchers, depending on the research objectives at hand, the best way forward is to approach the issue holistically and look at its various aspects from the perspectives of a combination of theoretical models.

\section{References}

Barley, S. R., \& Tolbert, P. S. (1997). Institutionalization and structuration: studying the links between action and institution. Organization Studies, 18(1), 93-117. http://dx.doi.org/10.1177/017084069701800106 
Bartram, T. (2011). Employee management systems and organizational contexts: a population ecology approach. Management Research Review, 34(6), 663-677. http://dx.doi.org/10.1108/01409171111136194

Baum, J. A. C., \& Oliver, C. (1991).Institutional Linkages and Organizational Mortality. Administrative Science Quarterly, 36, 187-218. http://dx.doi.org/10.2307/2393353

Baydas, M., Graham, D., \& Valenzuela, L. (1997).Commercial Banks in Microfinance: New Actors in the Microfinance World, Microenterprise Best Practices Project, USAID. Bethesda, Maryland: Development Alternatives, Inc.

Black, T. R. (2002). Understanding Social Science Research(2nd ed.). Thousand Oaks, California: Sage Publications. http://dx.doi.org/10.4135/9780857020208

Campanale, C., Cinquini, L., \& Tenucci, A. (2010). Do Management Accounting Systems Influence Organizational Change or Vice-Versa? Evidence from a Case of Constructive Research in the Healthcare Sector, Social Science Research Network. http://dx.doi.org/10.2139/ssrn.1656943

Cassell, C., \& Simon, G. (2011). Assessing 'good' qualitative research in the work psychology field: A narrative analysis. Journal of Occupational and Organizational Psychology, 84(4), 633-650. http://dx.doi.org/10.1111/j.2044-8325.2011.02009.x

Cernea, M. (1993). The Sociologist's Approach to Sustainable Development. Finance and Development, 30, $11-13$.

Consultative Group to Assist the Poor. (1996). Microcredit Interest Rates. Donor Brief No. 1, February, The World Bank: Washington, D.C.

Deephouse, D. L. (1996). Does isomorphism legitimate? Academy of Management Journal, 39(4), $1024-1039$. http://dx.doi.org/10.2307/256722

Dichter, T. W. (1996). Questioning the future of NGOs in microfinance. Journal of International Development, 8(2), 259-269. http://dx.doi.org/10.1002/(SICI)1099-1328(199603)8:2<259::AID-JID377>3.0.CO;2-7

DiMaggio, P. J., \& Powell, W. W. (1983). The iron cage revisited: institutional isomorphism and collective rationality in organizational fields. American Sociological Review, 48, 147-160. http://dx.doi.org/10.2307/2095101

Easterby-Smith, M., Thorpe, R., \& Lowe, A. (1991). Management research: an introduction. London: Sage Publications.

Edgcomb, E. L., \& Cawley, J. (1994). The process of institutional development: assisting small enterprise institutions become more effective. In M. Otero \& Rhyne, E. (Eds.), The New World of Microenterprise Finance: Building Healthy Institutions for the Poor (pp. 76-93), West Harford, C. T.: Kumarian Press.

Eisenhardt, K. M. (1988). Agency and institutional theory explanations: the case of retail sales competition. Academy of Management Journal, 30, 488-511. http://dx.doi.org/10.2307/256457

Erakovic, L., \& Wilson, M. (2005). Conditions of radical transformation in state-owned enterprises. British Journal of Management, 16, 293-313. http://dx.doi.org/10.1111/j.1467-8551.2005.00467.x

Fernando, J. L. (2006). Microcredit and empowerment of women: blurring the boundary between development and capitalism. In J. L. Fernando (Ed.), Microfinance: Perils and Prospects (pp. 1-42), New York: Routledge.

Fossey, E., Harvey, C., McDermott, F., \& Davidson, L. (2002). Understanding and evaluating qualitative research. Australian and New Zealand Journal of Psychiatry, 36, 717-732. http://dx.doi.org/10.1046/j.1440-1614.2002.01100.x

Fraser, M. (2012). Fleshing out' an engagement with a social accounting technology. Accounting, Auditing \& Accountability Journal, 25(3), 508-534. http://dx.doi.org/10.1108/09513571211209626

Gioia, D. A., \& Chittipeddi, K. (1991). Sense-making and sense-giving in strategic change initiation. Strategic Management Journal, 12, 433-448. http://dx.doi.org/10.1002/smj.4250120604

Gonzalez-Vega, C., \& Schreiner, M. (1997). The challenge of growth for microfinance organizations: the case of Banco Solidario in Bolivia. In H. Schneider (Ed.), Microfinance for the Poor? Washington D.C.: Organization for Economic Co-operation and Development (OECD).

Gray, R., Walters, D., Bebbington, J., \& Thompson, I. (1995). The greening of enterprise: an exploration of the (non) role of environmental accounting and environmental accountants in organizational change. Critical Perspectives on Accounting, 6, 211-239. http://dx.doi.org/10.1006/cpac.1995.1021 
Greenwood, R., \& Hinings, C. R. (1988). Organizational design types, tracks, and the dynamics of strategic change. Organization Studies, 9(3), 293-316. http://dx.doi.org/10.1177/017084068800900301

Guion, L. A., Diehl, D. C., \& McDonald, D. (2011). Triangulation: establishing the validity of qualitative studies. University of Florida: IFAS Extension. Retrieved June 20, 2014, from http://edis.ifas.ufl.edu/fy394

Gurgand, M., Pedersen, G., \& Yaron, J. (1996). Rural finance institutions in Sub-Saharan Africa: their outreach and sustainability. Savings and Development, 20(2), 135-169.

Haq, M., Skully, M., \& Pathan, S. (2010). Efficiency of microfinance institutions: a data envelopment analysis. Asia-Pacific Financial Markets, 17, 63-97. http://dx.doi.org/10.1007/s10690-009-9103-7

Hotho, J. J., Saka-Helmhout, A., \& Becker-Ritterspach, F. (2014). Bringing context and structure back into situated learning. Management Learning, 45(1), 57-80. http://dx.doi.org/10.1177/1350507612468420

Hussey, J., \& Hussey, R. (1997). Business research: a practical guide for undergraduate and postgraduate students. New York: Palgrave.

Issabella, L. A. (1990). Evolving interpretations as change unfolds: how managers construe key organizational events. Academy of Management Journal, 33(1), 7-41. http://dx.doi.org/10.2307/256350

Kassim, A. W., Tahajuddin, S., Hassan, M. G., Shamsuddin, A. S., \& Sulaiman, Y. B. (2011). Organizational change and pace: a conceptual link. International Conference on Management Proceeding, Penang, Malaysia.

Khan, A. A. (2008). Managing environmental turbulence in the microfinance sector-a case study of the Aga Khan Rural Support Programme in Pakistan. PhD thesis, School of Accounting and Finance, University of Wollongong, Retrieved from http://ro.uow.edu.au/theses/74

Kilfoyle E., \& Richardson, A. J. (2011). Agency and structure in budgeting: Thesis, antithesis and synthesis. Critical Perspective in Accounting, 22, 183-199. http://dx.doi.org/10.1016/j.cpa.2010.06.013

Laughlin, R. (1991). Environmental disturbances and organizational transitions and transformations: some alternative models. Organization Studies, 12(2), 209-232. http://dx.doi.org/10.1177/017084069101200203

Layder, D. (1993). New strategies in social research, Cambridge: Polity Press.

Lounsbury, M. (2008). Institutional rationality and practice variation: new directions in the institutional analysis of practice. Accounting, Organizations and Society, 33, 349-361. http://dx.doi.org/10.1016/j.aos.2007.04.001

Lowrey, W., \& Woo, C. W. (2010). The News Organization in Uncertain Times: Business or Institution? Journalism \& Mass Communication Quarterly, 87(1), 41-61. http://dx.doi.org/10.1177/107769901008700103

Meyer, J. W., \& Rowan, B. (1977). Institutionalized organizations: formal structure as myth and ceremony. American Journal of Sociology, 1, 340-363. http://dx.doi.org/10.1086/226550

Mills, A. J., \& Murgatroyd, S. J. (1991). Organizational rules: a framework for understanding organizational action. Philadelphia: Open University Press.

Mohan, L., \& Potnis, D. (2010). Catalytic innovation in microfinance for inclusive growth: insights from SKS Microfinance. Journal of Asia-Pacific Business, 11(3), 218-239. http://dx.doi.org/10.1080/10599231.2010.500574

Munhall, P. L. (2011). A phenomenological method. In P. L. Munhall (Ed.), Nursing Research: A Qualitative Perspective (5th ed., pp. 113-175). Ontario, Canada: Jones \& Bartlett Learning.

Oliver, C. (1997). The influence of institutional and task environment relationships on organizational performance: the canadian construction industry. Journal of Management Studies, 34(1), 99-124. http://dx.doi.org/10.1111/1467-6486.00044

Patton, M. Q. (2002). Qualitative evaluation and research methods (3rd ed.). Thousand Oaks, California: Sage Publications.

Pettigrew, A. (1987). Context and action in the transformation of the firm. Journal of Management Studies, 24(6), 649-670. http://dx.doi.org/10.1111/j.1467-6486.1987.tb00467.x

Pfeffer, J., \& Salancik, G. (1978). The External Control of Organizations. New York: Harper \& Row.

Piore, M. J. (1983). Qualitative research techniques in economics. In J. Van Maanen (Ed.), Qualitative Methodology. London: Sage Publications. 
Rahman, M. W., \& Luo, J. (2011). The development perspective of finance and microfinance sector in china: how far is microfinance regulations? International Journal of Economics and Finance, 3(1), 160-170. http://dx.doi.org/10.5539/ijef.v3n1p160

Remenyi, D., Williams, B., Money, A., \& Swartz, E. (1998). Doing research in business and management: an introduction to process and method. London: Sage Publications.

Rice, P. L., \& Ezzy, D. (1999). Qualitative research methods, a health focus. Melbourne: Oxford University Press.

Robinson, M. S. (2001). The microfinance revolution: sustainable finance for the poor. Washington, D. C.: The World Bank. http://dx.doi.org/10.1596/0-8213-4524-9

Robinson, M. S. (2002). The Microfinance Revolution: Lessons from Indonesia. Washington, D. C.: The World Bank. http://dx.doi.org/10.1596/0-8213-4953-8

Rogaly, B. (1996). Micro-finance evangelism, 'destitute women' and the hard selling of a new anti-poverty formula. Development in Practice, 6(2), 100-112. http://dx.doi.org/10.1080/0961452961000157654

Scott, W. R. (1995). Institutions and organizations. Thousand Oaks, USA: Sage Publications.

Selznick, P. (1957). Leadership in administration: a sociological interpretation. New York: Harper \& Row.

Shanikat, M. (2008). Organisational change and accounting information systems: a case study of the privatisation of Jordan Telecom. PhD thesis, School of Accounting and Finance, University of Wollongong. Retrieved from http://ro.uow.edu.au/theses/103

Snow, D. (1999). Microcredit: An Institutional Development Opportunity. International Journal of Economic Development, 1(1), 65-79.

Strauss, A., \& Corbin, J. (1990). Basics of qualitative research: grounded theory procedures and techniques. London: Sage Publications.

Tolbert, P. S. (1985). Institutional environments and resource dependence: sources of administrative structure in institutions of higher education. Administrative Science Quarterly, 30, 1-13. http://dx.doi.org/10.2307/2392808

Tyrrall, D., \& Parker, D. (2005). The fragmentation of a railway: a study of organizational change. Journal of Management Studies, 42(3), 507-537. http://dx.doi.org/10.1111/j.1467-6486.2005.00507.x

Van Maanen, J. (1983). Qualitative methodology. London: Sage Publications.

Weick, K. E. (1996). An appreciation of social context: one legacy of Gerald Salancik. Administrative Science Quarterly, 41, 563-573. http://dx.doi.org/10.2307/2393867

Yin, R. K. (2003). Case study research: design and methods. Thousand Oaks, London: Sage Publications.

\section{Notes}

Note 1. A theory is "a set of interrelated variables, definitions and propositions that presents a systematic view of phenomena by specifying relationships among variables with the purpose of explaining natural phenomena" (Hussey \& Hussey, 1997, p. 52).

Note 2. The term 'data' refers to "known facts or things used as a basis for inference or reckoning" (Hussey \& Hussey, 1997, p. 118).

Note 3. The term 'international donor community', referred to as 'donors', 'donor community', or 'donor agencies' connotes international sources of subsidized funding for the poor. This includes bi-lateral and multi-lateral financial organizations such as the Consultative Group to Assist the Poor (CGAP), The World Bank, and the Asian Development Bank (ADB), among others.

Note 4. The term 'phenomenological' stems from the word 'phenomenon' which means 'a fact or occurrence that appears or is perceived' in a particular context (Hussey \& Hussey, 1997, p. 52).

Note 5. In very broad terms, organizations could be referred to as 'self-sustainable' if the society is deemed to be receiving benefits, net of all costs, from their existence (Cernea, 1993). 


\section{Copyrights}

Copyright for this article is retained by the author(s), with first publication rights granted to the journal.

This is an open-access article distributed under the terms and conditions of the Creative Commons Attribution license (http://creativecommons.org/licenses/by/3.0/). 